ISSN 1810-3030 (Print) 2408-8684 (Online)

\title{
Effect of aerated and non-aerated compost tea against some fungal phytopathogens
}

\author{
Rinita Islam, Sabiha Sultana, Md. Rejaul Islam and ${ }^{\bowtie}$ Chhoa Mondal
}

Agrotechnology Discipline, Khulna University, Khulna- 9208

\begin{tabular}{|c|c|}
\hline ARTICLE INFO OPEN ${ }^{\text {Access }}$ & Abstract \\
\hline $\begin{array}{l}\text { Article history: } \\
\text { Received : } 31 \text { August } 2018 \\
\text { Accepted : 14 May } 2019 \\
\text { Published: } 30 \text { June } 2019 \\
\end{array}$ & \multirow{3}{*}{$\begin{array}{l}\text { Suppressive effect of aerated and non-aerated compost tea against different fungal phytopathogens, } \\
\text { namely Alternaria solani, Bipolaris sorokiniana, Fusarium oxysporum, Pestalotia palmarum and } \\
\text { Sclerotium rolfsii was evaluated in Plant Protection Laboratory of Agrotechnology Discipline, Khulna } \\
\text { University, Khulna, Bangladesh during } 2016 \text {. Commercial compost, "Rastic Joibo Shar" was used to } \\
\text { prepare aerated and non-aerated compost teas at } 20 \% \text { and } 25 \% \text { concentrations. All the treatments } \\
\text { significantly inhibited the mycelial growth of tested five fungal phytopathogens. Among the five } \\
\text { pathogens } 25 \% \text { concentration of non-aerated compost tea gave highest mycelial growth inhibition ( } 76 \% \text { ) } \\
\text { of Sclerotium rolfsii. Colony characteristics of five phytopathogens were significantly varied in all aspect } \\
\text { by treating aerated and non-aerated compost teas at different concentrations. Finally it may be concluded } \\
\text { that both aerated and non-aerated compost teas have suppressing effect on radial mycelial growth Thus } \\
\text { compost tea may be used as alternatives to inorganic fertilizers/fungicides to suppress the pathogenic } \\
\text { activity of the soil borne fungal phytopathogens. Thus based on the efficacy of in-vitro experiments, } \\
\text { efficacy in field condition can be assessed against different diseases. }\end{array}$} \\
\hline $\begin{array}{l}\text { Keywords: } \\
\text { Compost Tea, fungal } \\
\text { phytopathogens, mycelial } \\
\text { inhibition, Sclerotium rolfsii }\end{array}$ & \\
\hline $\begin{array}{l}\text { Correspondence: } \\
\text { Chhoa Mondal } \\
\text { 凶: chhoa_at } 07 @ \text { yahoo.com }\end{array}$ & \\
\hline
\end{tabular}

Copyright:

(c) (1)

(C2019 by authors and BAURES. This work is licensed under the Creative Commons Attribution International License (CC By 4.0).

\section{Introduction}

The majority of the fungal species are saprophytic, with around $10 \%$ (more or less 100000 fungal species) can colonize plants and cause plant disease (Agrios, 1997). Among the fungal phytopatogens, soil-borne and seedborne are most devastating to crops. Most Alternaria species are saprophytes that are commonly found in soil or on decaying plant tissues (Thomma, 2003). Early blight of potato and tomato are the most destructive foliar diseases caused by Alternaria solani. The yield loss due to early blight ranges from $5 \%-78 \%$ in both tomato and potato (Waals et al., 2004; Pasche et al., 2005). Cereal production is seriously hampered by foliar diseases caused by Bipolaris spp. The pathogen reduced the average yield $70 \%$ to $80 \%$ in barley and wheat respectively (Alam et al, 1994). The grain/ear in both crops is also reduced to $88.7 \%$ (Hossain et al., 1998). Fusarium spp. is one of the most common soil born fungi. Vascular wilt of tomato caused by $F$. oxysporum may cause complete yield loss (Walker, 1971; Benhamou et al., 1998). Pestalotia pulmarum causes grey leaf spot of coconut and betel nut of the coastal area of Bangladesh. Every year leaf spot disease attacks the gardens of coconut and betel nut and causes as much as $14 \%$ yield loss (Islam et al., 2004). Sclerotium spp. especially Sclerotium rolfsii is a serious soil-borne plant pathogen of many crops (Aycock, 1966). Seedling blight, foot rot, collar rot and southern blight etc. are the most common diseases incited by $S$. rolfsii (Khan and Kibria, 1973).
Generally, the control of soil-borne diseases is very difficult and chemical soil fumigation as the only possible way for remedy because of its effectiveness. However, the transition toward sustainable plant disease management required by the EU, through restrictive policies on the use of synthetic fungicides, has stimulated research into valid alternative methods equally capable of reducing losses due to plant diseases (Ariena et al., 2015). Use of aerated compost teas (ACTs) is becoming an attractive disease management option among producers who support sustainable protective methods. ACTs are liquid products generally derived from aerated aqueous extractions of composted biodegradable organic compounds (Ingham et al., 2003). Aerated and non-aerated compost teas, both products of compost, have also been shown to suppress soil-borne diseases, including damping-off and root rots caused by Pythium ultimum, Rhizoctonia solani (Scheuerell and Mahaffee, 2002; Dionne et al. 2012), Phytophthora capcisi (Sang et al., 2010) and wilts caused by Fusarium oxysporum and Verticillium dahliae (Alfano et al., 2011). Hibar et al. (2005) demonstrated that transplanting inoculated tomato seedlings in compost extract-treated peat inhibited Fusarium oxysporum. In fact, there are a number of reports that demonstrate the ability of compost tea to suppress a wide range of both air- and soil-borne plant pathogens, when applied as foliar spray and soil drenching (Scheuerell and Mahaffee, 2002). 
A number of studies have indicated that the microbial community of CT is effective for disease suppression (Hoitink et al., 1997; Siddiqui et al., 2008). Reduction and elimination of the adverse effects of synthetic fertilizers and pesticides on human health and the environment is a strong indicator that organic agriculture is gaining worldwide attention. Because indiscriminate use of chemicals for controlling diseases of crop plants result environmental pollution and health hazards as well as reduce soil quality (Martin and Brathwaite, 2012). Different works have been reported as single or multiple mechanisms involving microbial antagonism through antibiosis, parasitism, competition for nutrients/space or induced plant resistance (Zhang et al. 1998; El-Masry et al. 2002; Al-Mughrabi et al. 2008), or suppressive physicochemical properties such as an improved nutrient status of the plant, toxic compounds, or induced resistance (Hoitink et al. 1997; Siddiqui et al. 2008). In this regard, compost teas are potential alternatives to the use of the common synthetic fungicides in response to environmental sustainability and food safety.

The present study has focused on the evaluation of the efficacy of aerated (ACT) and non-aerated compost teas for in-vitro suppression of different fungal phytopathogens such as Alternaria solani, Bipolaris sorokiniana, Fusarium oxysporum, Pestalotia pulmarum and Sclerotium rolfsii.

\section{Materials and Methods}

\section{Sample collection and isolation of fungi}

Infected tomato plants with typical symptoms of early blight and wilt were collected from Dumuria upazilla under Khulna district. The fungus was isolated following tissue planting method (Mian, 1995). It was identified observing morphological characters by using key described in Barnett and Hunter (1972). The pure culture of the fungus was obtained by Hyphal Tip Isolation Method. These fungal isolates were grown on PDA slants, stored at $4^{0} \mathrm{C}$ in a refrigerator for further use. The preserved isolates of Bipolaris sorokiniana, Pestalotia palmarum and Sclerotium rolfsii were collected from the Plant Protection laboratory of Agrotechnology Discipline, Khulna University, Khulna, Bangladesh and used in this experiment.

Laboratory experiment was conducted at Plant Protection Laboratory of Agrotechnology Discipline, Khulna University, Khulna, Bangladesh during October, 2016 to November, 2016.

\section{Multiplication of Fungi}

Sterilized petridishes were placed in aseptic condition of a laminar air flow cabinet and 20ml PDA was poured in each petridish. After solidification of PDA, the plates were inoculated by placing $5 \mathrm{~mm}$ disc of four days old pure culture of Alternaria solani, Bipolaris sorokiniana, Fusarium oxysporum, Pestalotia palmarum and Sclerotium rolfsii using flame sterilized cork-borer (5 $\mathrm{mm}$ diameter). The inoculated petridishes were marked and kept in the growth chamber at $24 \pm 1{ }^{\circ} \mathrm{C}$ for few days.

\section{Preparation of Aerated and Non-Aerated Compost Tea (ACT\& NCT)}

Commercially available compost named "Rastic Compost Joiboshar" was collected from the local market of Khulna city. For preparing ACT, 400 gm of compost was kept and equally distributed in eight conical flasks (50 gm/conical flask). Among them, four conical flasks, each of the flask was poured with $150 \mathrm{ml}$ sterile distilled water and rest four conical flasks were poured with 200 $\mathrm{ml}$ sterile distilled water to prepare $25 \%$ and $20 \%$ concentrations respectively. The mixture was homogenized in orbital shaker at $250 \mathrm{rev} / \mathrm{min}$ and $25^{\circ} \mathrm{C}$ for 14 days under dark condition. After 14 days, the homogeneous solution was filtered with cheese cloth and the extracts were used to conduct the experiment (Martin et al., 2013).

To obtain NCT, $400 \mathrm{gm}$ of compost was kept in an airtight container at $25^{\circ} \mathrm{C}$ for 14 days under dark condition. After 14 days, above (ACT preparation) same procedures were followed to prepare $25 \%$ and $20 \%$ concentrations respectively. The mixture was homogenized in an orbital shaker at $250 \mathrm{rev} / \mathrm{min}$ and 25 ${ }^{\circ} \mathrm{C}$ for 10 minutes for homogenize the solution.

\section{Inoculation and Incubation}

To get aerated or non-aerated compost tea media, the basic PDA media was modified by using aerated or nonaerated compost teas at $15 \%$ concentration. The fungi were grown on modified PDA (17 ml basic PDA media and $3 \mathrm{ml}$ aerated compost tea) medium, each petridish containing $20 \mathrm{ml}$ of modified media. Basic PDA media with $15 \%$ sterilized distilled water was used as control. The composition of the inoculation media are presented in Table 1.

Table 1. Concentration of the inoculation media used in experiment (Martin et al, 2013)

\begin{tabular}{|c|c|c|c|}
\hline \multirow[t]{2}{*}{ Treatment } & \multirow{2}{*}{$\begin{array}{c}\text { Concentration } \\
\text { of treatment } \\
(\%)\end{array}$} & \multicolumn{2}{|c|}{ Concentration of media (\%) } \\
\hline & & $\begin{array}{c}\text { Treatment } \\
(\mathrm{mL})\end{array}$ & $\begin{array}{l}\text { PDA media } \\
(\mathrm{mL})\end{array}$ \\
\hline Aerated compost & 20 & 20 & 80 \\
\hline tea & 25 & 25 & 75 \\
\hline Non-aerated & 20 & 20 & 80 \\
\hline compost tea & 25 & 25 & 75 \\
\hline $\begin{array}{l}\text { Sterilized distilled } \\
\text { water (Control) }\end{array}$ & - & 20 or 25 & 80 or 75 \\
\hline
\end{tabular}

The $\mathrm{pH}$ of all the media were adjusted to 6.5 by adding alkaline solution $(0.1 \% \quad \mathrm{NaOH})$. The plates were inoculated and incubated at $24 \pm 1^{\circ} \mathrm{C}$. The radial mycelia growth of each plate was recorded considering $80 \%$ radial growth of control treatment.

\section{Measurement of Radial Growth and Determination of Percentage Inhibition}

The radial growth of mycelium of each plate was recorded as an average of two diameters measured at 
right angles to one another. The colony characters were recorded. The percentage inhibition of growth over control was calculated using the following formula ( $\mathrm{Naz}$ et al., 2006).

$\%$ inhibition $=\frac{X-Y}{X} \times 100$

Where,

$\mathrm{X}=$ Average growth of fungi in control petridish

$\mathrm{Y}=$ Average growth of fungi in each treated petridish

\section{Observation of Colonial Character}

After completion of $80 \%$ radial growth in control treatment, mycelial characters such as shape, structure, texture, and colony color of top view and reverse view were observed visually and recorded.

\section{Experimental Design and Data Analysis}

Completely randomized design was followed for conducting experiment. Five replications were used for each treatment. The data were statistically analyzed using STAR (Statistical Tool for Agricultural Research) computer program and means were compared following Duncan's Multiple Range Test (DMRT).

\section{Results and Discussion}

\section{Effect of compost teas on radial mycelial growth}

Radial mycelial growth significantly varied for both the aerated and non-aerated compost teas at different concentrations (Table 2). In case of Alternaria solani and Bipolaris sorokiniana aerated compost teas indicated lowest mycelia growth $(30 \mathrm{~mm}$ and $22 \mathrm{~mm}$, respectively). A similar effect was observed by Martin et al. (2014) who showed that aerated compost teas (ACT) from all sources generally gave rise to greater in vitro suppression than non-aerated compost teas (NCT), although both are considered effective. Haggag and Saber (2007), also found that both ACT and NCT from either plant residues or chicken manure compost inhibited conidium germination of Alternaria porri (purple blight) and A. solani (early blight) in in vitro experiments.

On the other hand, non-aerated compost teas reduced mycelia growth of Fusarium oxysporum, Pestalotia palmarum and Sclerotium rolfsii and lowest mycelia growth were $28 \mathrm{~mm}, 25 \mathrm{~mm}$ and $19 \mathrm{~mm}$, respectively (Table 2). Cronin et al, (1996) concluded that NCT from manure-based spent mushroom compost effectively inhibited the in vitro conidium germination of Venturia inaequalis (apple scab), whereas ACT had no effect.

Previous reports have shown that compost teas affect the mycelial growth of numerous plant pathogens (e.g. Scheuerell and Mahaffee, 2004 and 2006; Haggag and Saber, 2007; Al-Mughrabi et al., 2008; Siddiqui et al., 2008; Koné et al., 2010). In particular, aerated grape marc compost tea greatly inhibited the mycelial growth of numerous soilborne fungi, including $F$. oxysporum $\mathrm{f}$. sp. lycopersici, $F$. oxysporum f. sp. radiciscucumerinum, $R$. solani, $V$. dahliae and $V$. fungicola (Diánez et al., 2006).

\section{Effect of compost teas on inhibition percentage}

The statistical bar (Figure 1) represents inhibition percentages were statistically significant for both the aerated and non-aerated compost teas at different concentrations. In case of Alternaria solani and Bipolaris sorokiniana aerated compost tea at $25 \%$ indicated highest inhibition percentage $(61 \%$ and $70 \%$, respectively) but non-aerated compost tea at $25 \%$ showed highest inhibition percentage in case of Fusarium oxysporum (64\%), Pestalotia palmarum $(68 \%)$ and Sclerotium rolfsii $(76 \%)$. Among five tested fungal phytopathogens Sclerotium rolfsii at $25 \%$ aerated compost tea concentration showed highest inhibition percentage (76\%) (Fig. 1).

Martin et al. (2013) showed that ACT and NCT filtrates inhibited the in vitro growth of all tested pathogens (Botrytis cinerea, Sclerotinia sclerotiorum, Pythium aphanidermatum, Phytophthora parasitica, Fusarium oxysporum) reaching $100 \%$ inhibition in most cases. Akter et al. (2013) reported that using different aqueous plant extracts in combination with compost teas at $2.5 \%$ concentration gave $91 \%$ inhibition of conidial germination of B. sorokiniana. Kone et al. (2010) also found significant inhibition of the mycelial growth of $A$. solani (37-66\%), B. cinerea (57-75\%) and P. infestans (100\%) for all non-aerated compost teas. Mechanisms of action underlying the efficacy of compost teas to control plant pathogens have been reported as single or multiple mechanisms involving microbial antagonism (through antibiosis, parasitism, competition for nutrients/space or induced plant resistance) (Zhang et al., 1998; El-Masry et al., 2002; Al Mughrabi et al., 2008) or suppressive physicochemical properties (improved nutrient status of the plant, toxic compounds or induced resistance) (Hoitink et al., 1997; Siddiqui et al., 2008).

Table 2. Effect of compost teas on radial mycelial growth of five fungal pathogens

\begin{tabular}{|c|c|c|c|c|c|}
\hline \multirow[t]{2}{*}{ Compost Tea } & \multicolumn{5}{|c|}{ Mycelial growth } \\
\hline & $\begin{array}{c}\text { Alternaria } \\
\text { solani }\end{array}$ & $\begin{array}{c}\text { Bipolaris } \\
\text { sorokiniana }\end{array}$ & $\begin{array}{c}\text { Fusarium } \\
\text { oxysporum }\end{array}$ & $\begin{array}{l}\text { Pestalotia } \\
\text { palmarum }\end{array}$ & $\begin{array}{c}\text { Sclerotium } \\
\text { rolfsii }\end{array}$ \\
\hline Control & $78 \mathrm{a}$ & $75 \mathrm{a}$ & $79 \mathrm{a}$ & $78 \mathrm{a}$ & $78 \mathrm{a}$ \\
\hline Aerated compost tea at $20 \%$ & $35 \mathrm{~b}$ & $22 \mathrm{~d}$ & $40 \mathrm{~b}$ & $34 \mathrm{~b}$ & $36 \mathrm{~b}$ \\
\hline Aerated compost tea at $25 \%$ & $30 \mathrm{c}$ & $22 \mathrm{~d}$ & $34 \mathrm{c}$ & $32 \mathrm{c}$ & $30 \mathrm{c}$ \\
\hline Non-aerated compost tea at $20 \%$ & $36 \mathrm{~b}$ & $31 \mathrm{~b}$ & $31 \mathrm{~d}$ & $27 \mathrm{~d}$ & $28 \mathrm{c}$ \\
\hline Non-aerated compost tea at $25 \%$ & $35 \mathrm{~b}$ & $26 \mathrm{c}$ & $28 \mathrm{e}$ & $25 \mathrm{~d}$ & $19 \mathrm{~d}$ \\
\hline LSD & 2.02 & 1.67 & 2.01 & 2.97 & 2.97 \\
\hline Level of significance $(\%)$ & 0.01 & 0.01 & 0.01 & 0.01 & 0.01 \\
\hline
\end{tabular}




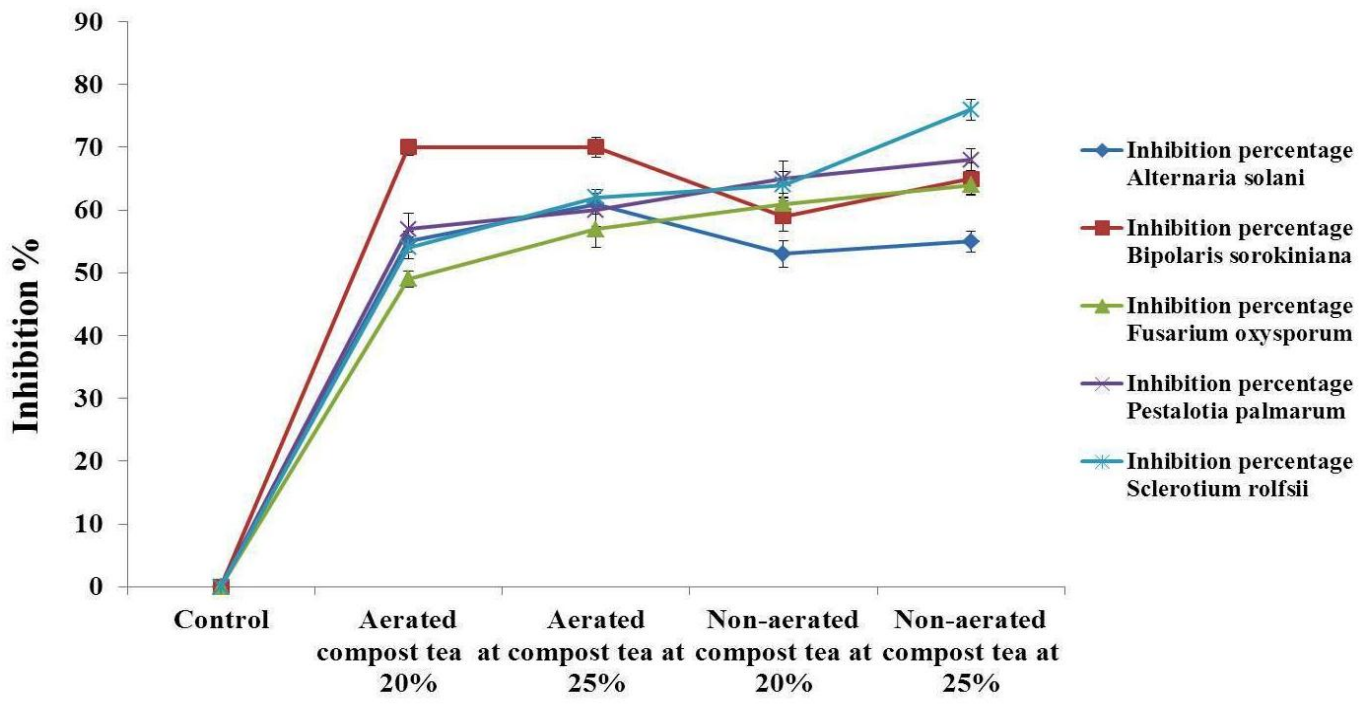

Treatments

Fig. 1. Effect of compost teas on Inhibition percentage over control of five fungal pathogens

Table 3. Effect of compost teas on colony characters of five fungal pathogens

\begin{tabular}{|c|c|c|c|c|c|c|}
\hline \multirow[t]{2}{*}{ Name of fungus } & \multirow[t]{2}{*}{ Compost Tea } & \multicolumn{5}{|c|}{ Colony characters } \\
\hline & & Shape & Texture & Margin & $\begin{array}{c}\text { Color (upper } \\
\text { surface) }\end{array}$ & $\begin{array}{c}\text { Color (lower } \\
\text { surface) }\end{array}$ \\
\hline \multirow{5}{*}{$\begin{array}{l}\text { Alternaria } \\
\text { solani }\end{array}$} & Control & Circular & Compact & Regular & Olive green & Dark green \\
\hline & Aerated compost tea at $20 \%$ & Circular & Cottony & Irregular & Olive green & Black \\
\hline & Aerated compost tea at $25 \%$ & Circular & Cottony & Irregular & Olive green & Black \\
\hline & Non-aerated compost tea at $20 \%$ & Circular & Cottony & Regular & Olive green & Black \\
\hline & Non-aerated compost tea at $25 \%$ & Circular & Cottony & Irregular & Olive green & Black \\
\hline \multirow{5}{*}{$\begin{array}{l}\text { Bipolaris } \\
\text { sorokiniana }\end{array}$} & Control & Irregular & Compact & Regular & Black & Black \\
\hline & Aerated compost tea at $20 \%$ & Irregular & Compact & Irregular & Grayish & Black \\
\hline & Aerated compost tea at $25 \%$ & Irregular & Compact & Irregular & Grayish & Black \\
\hline & Non-aerated compost tea at $20 \%$ & Irregular & Compact & Irregular & Grayish & Black \\
\hline & Non-aerated compost tea at $25 \%$ & Irregular & Compact & Irregular & Grayish & Black \\
\hline \multirow{5}{*}{$\begin{array}{l}\text { Fusarium } \\
\text { oxysporum }\end{array}$} & Control & Circular & Feathery & Regular & Pink & Creamy \\
\hline & Aerated compost tea at $20 \%$ & Circular & Feathery & Regular & Pink & Creamy \\
\hline & Aerated compost tea at $25 \%$ & Irregular & Feathery & Regular & Pink & Creamy \\
\hline & Non-aerated compost tea at $20 \%$ & Circular & Feathery & Irregular & Pink & Creamy \\
\hline & Non-aerated compost tea at $25 \%$ & Circular & Feathery & Regular & Pink & Creamy \\
\hline \multirow{5}{*}{$\begin{array}{l}\text { Pestalotia } \\
\text { palmarum }\end{array}$} & Control & Circular & Compact & Regular & White & White \\
\hline & Aerated compost tea at $20 \%$ & Circular & Compact & Regular & White & White \\
\hline & Aerated compost tea at $25 \%$ & Circular & Compact & Regular & White & White \\
\hline & Non-aerated compost tea at $20 \%$ & Circular & Compact & Regular & White & White \\
\hline & Non-aerated compost tea at $25 \%$ & Circular & Compact & Regular & White & White \\
\hline \multirow{5}{*}{$\begin{array}{l}\text { Sclerotium } \\
\text { rolfsii }\end{array}$} & Control & Circular & Compact & Regular & White & Reddish \\
\hline & Aerated compost tea at $20 \%$ & Circular & Compact & Regular & White & Reddish \\
\hline & Aerated compost tea at $25 \%$ & Circular & Compact & Irregular & White & Reddish \\
\hline & Non-aerated compost tea at $20 \%$ & Irregular & Compact & Irregular & White & Reddish \\
\hline & Non-aerated compost at $25 \%$ & Circular & Compact & Irregular & White & Reddish \\
\hline
\end{tabular}

Effect of compost teas on colony characters

Circular shaped mycelial colony was recorded in Alternaria solani, Fusarium oxysporum, Pestalotia palmarum and Sclerotium rolfsii at all concentration of compost teas except aerated compost tea $25 \%$ in case of Fusarium oxysporum and Non-aerated compost tea at $20 \%$ in case of Sclerotium rolfsii which showed irregular shape. Bipolaris sorokiniana showed irregular shape at all level of concentration.

Control plate of Alternaria solani and all concentration plate of Bipolaris sorokiniana, Pestalotia palmarum and Sclerotium rolfsii revealed compact texture; other plates of Alternaria solani showed cottony texture. Feathery texture was found from Fusarium oxysporum. 
Regular margin were found from all the control plate of five fungi, all the concentration of compost tea of Pestalotia palmarum, Non-aerated compost tea at $20 \%$ of Alternaria solani; Aerated compost tea at $20 \%$ and $25 \%$, Non-aerated compost tea at $25 \%$ of Fusarium oxysporum and aerated compost tea at $20 \%$ of Sclerotium rolfsii. Remaining others showed irregular margin.

The upper surface colony color of Alternaria solani was olive green, Bipolaris sorokiniana was grayish but the control plate was black, Fusarium oxysporum was pink and Pestalotia palmarum and Sclerotium rolfsii were white. That means application of compost tea affected only the upper surface colony color of Bipolaris sorokiniana.

Dark green lower surface colony color was observed on control plate of Alternaria solani; other treatment of Alternaria solani and Bipolaris sorokiniana showed black color. Creamy, white and reddish color were observed from Fusarium oxysporum, Pestalotia palmarum and Sclerotium rolfsii, respectively. So compost tea affected only the lower surface colony color of Alternaria solani (Table 3).

Overall, results from this study showed that both ACT and NCT provided a significant inhibition of the mycelial growth of soil-borne pathogens as well as seedborne pathogens. Among the five Phytopathogens highest inhibition was found in $S$. rolfsii. So, compost tea could play important role to suppress the pathogenic activity of S. rolfsii. Future work will be attempted to identify more accurate concentration and application procedure to suppress diseases and enhancing plant growth in field condition.

\section{References}

Agrios, G.N. 1997. Plant Pathology. 4th ed. Academic Press, pp. 635.

Akter, S., M. A. Latif, A. T. Mia, T. H. Ansari, M. T. Islam and M. Y. Rafii, 2013. Efficacy of fungicides against grain spot disease in rice (Oryza sativa). Life Science Journal, 10(4); 3005-3008.

Alam, K. B., Shaheed, M. A., Ahmed, A. U. and Malakar, P. K. 1994. Bipolaris leaf blight (spot blotch) of wheat in Bangladesh. In Sunders, D. A, Hattel, G.P. (Eds.) Wheat in Heat Stressed Environment: Irrigated, Dry Areas and Rice-wheat Systems. CIMMYT, Mexico, pp. 339-342.

Alfano, G., Lustrato, G., Lima, G., Vitullo, D. and Ranalli, G. 2011. Characterization of composted olive mill wastes to predict potential plant disease suppressiveness. Biological Control, 58(3): 199-207. https://doi.org/10.1016/j.biocontrol.2011.05.001

Al-Mughrabi, K.I., Bertheleme, C., Livingston, T., Burgoyne, A., Poirier, R. and Vikram, A. 2008. Aerobic compost tea, compost and a combination of both reduce the severity of common scab (Streptomyces scabiei) on potato tubers. Journal of Plant Sciences, 3(2): 168-175. https://doi.org/10.3923/jps.2008.168.175

Ariena, H.C van B., Abraham, G., and Maria, R. F. 2015. Plant disease management in organic farming systems. (wileyonlinelibrary.com) DOI 10.1002/ps.4145

Aycock, R. 1966. Stem rot and other diseases caused by Sclerotium rolfsii or the status of Rolf's fungus after 70 years. North
Carolina Agricultural Experiment Station. Technical bulletin, 174 .

Barnett, H. L. and Hunter, B. B. 1972. Illustrated Genera of Imperfect Fungi. 3rd Edition, Burgess Publishing Company, Minneapolis, pp. 241.

Benhamou, N., Kloepper, J. W. and Tuzun, S. 1998. Induction of resistance against Fusarium wilt of tomato by combination of chitosan with an endophytic bacterial strain: ultrastructure and cytochemistry of the host response. Planta, 204(2): 153-168. https://doi.org/10.1007/s004250050242

Cronin, M.J., Yohalem, D.S., Harris, R.F. and Andrews, J.H. 1996. Putative mechanism and dynamics of inhibition of the apple scab pathogen Venturia inaequalis by compost extracts. Soil Biology and Biochemistry, 28: 1241-1249. https://doi.org/10.1016/0038-0717(96)00131-9

Dianez, F., Santos, M., Boix, A., De-Cara, M., Trillas, I., Aviles, M. and Tello, J.C. 2006. Grape marc compost tea suppressiveness to plant pathogenic fungi: role of siderophores. Compost science \& utilization, 14(1): 48-53. https://doi.org/10.1080/1065657X.2006.10702262

Dionne, A., Tweddell, R.J., Antoun, H. and Avis, T.J. 2012. Effect of non-aerated compost teas on damping-off pathogens of tomato. Canadian Journal of Plant Pathology, 34(1): 5157. https://doi.org/10.1080/07060661.2012.660195

El-Masry, M.H., Khalil, A.I., Hassouna, M.S. and Ibrahim, H.A.H. 2002. In situ and in vitro suppressive effect of agricultural composts and their water extracts on some phytopathogenic fungi. World Journal of Microbiology and Biotechnology, 18: 551-558. https://doi.org/10.1023/A:1016302729218

Haggag, W.M. and Saber, M.S.M. 2007. Suppression of early blight on tomato and purple blight on onion by foliar sprays of aerated and non-aerated compost teas. Journal of Food, Agriculture and Environment, 5: 302-309.

Hibar, K., Daami-Remadi, M., Khaireddine, H. and El Mah- joub, M. 2005. Effet inhibiteur In vitro et In vivo du Trichoderma harzianum sur Fusarium oxysporum $f$. sp. radicislycopersici. Biotechnology, Agronomy, Society and Environment, 9(3): 163-171.

Hoitink, H. A., Stone, A. G. and Han, D.Y. 1997. Suppression of plant diseases by composts. Hortscience, 32: 184-187. https://doi.org/10.21273/HORTSCI.32.2.184

Hossain I., Rashid, A. Q. M. B, Fakir, G. A. and Meah., M. B. 1998. Leaf blight of wheat, its status and impact on grain formation. First National Workshop on Seed Pathology. Progress and Prospect of Seed Pathology Research in Bangladesh. Department of Plant Pathology, Bangladesh Agricultural University, Mymensingh, Bangladesh, pp. 910.

Ingham, E.R. 2003. The Compost Tea Brewing Manual. Fourth ed. Soil Food Web Inc., Corvallis, Oregon, USA.

Islam, M.R., Hossain, M.K., Bahar, M. H. and Ah, M.R., 2004. Identification of the causal agent of leaf spot of betelnut an in vitro evaluation of fungicides and plant extracts against it. Pakistan journal of Biological Science, 7: 1758-1761. https://doi.org/10.3923/pjbs.2004.1758.1761

Khan, A. A. and Kibria, M. G. 1973. A note on the outbreak of Sclerotium wilt of potato at Bangladesh Agricultural University Farm. Bangladesh Horticulture, 1 (2): 8081 Kone, S.B., Dionne, A., Tweddell, R.J., Antoun, H. and Avis, T.J. 2010. Suppressive effect of non-aerated compost teas on foliar fungal pathogens of tomato. Biological Control, 52(2); 167-173. https://doi.org/10.1016/j.biocontrol.2009.10.018

Martin, C.G. and Brathwaite, R.A.I. 2012. Compost and compost tea: principles and prospects as management strategies in soilless vegetable production. Biological Agriculture \& Horticulture, 28(1):1-33. https://doi.org/10.1080/01448765.2012.671516

Martin, F., dianez, F., Santos, M., Carretero, Gea, F., F. J., Castaneda, C., Navarro, M. J. and Yau, J. 2014. Control of Phytophthora capsici and Phytophthora parasitica on pepper (Capsicum annuum L.) with compost teas from different sources, and their effects on plant growth promotion. Phytopathologia Mediterranea, 53(2):216-228. 
Martin, F., Santos, M., Dianez, F., Carretero, F., Gea, F. J., Yau, J. A. and Navarro, M. J. 2013. Characters of compost teas from different sources and their suppressive effect on fungal phytopathogens. World Journal of Microbiology and Biotechnology, 29(8): 1371-1382. https://doi.org/10.1007/s11274-013-1300-x

Mian, M. S., Khan, S. A., Zaidi, F.H., Chaudhry, R.A., Ashraf S.K. and Qureshi. I.R. 1995. Comparative study on pathology of hemic system of three broiler chicken strains suffering from experimental hydropericardium syndrome. AsianAustralasian Journal of Animal Sciences, 8(4): 325-328. https://doi.org/10.5713/ajas.1995.325

Naz, F., Rauf, C.A., Haque, I.U. and Ahmad, I. 2006. Management of Fusarium oxysporium with Plant Diffustates and Chemicals. Pakistan Journal of Phytopathology, pp. 36-43.

Pasche J. S., Piche, L.M. and Gudmestad, N.C. 2005. Effect of the F129L mutation in Alternaria solani on fungicides affecting mitochondrial respiration. Plant Disease, 89: 269-278. https://doi.org/10.1094/PD-89-0269

Sang, M.K., Kim, J.G., Kim, K.D. 2010. Biocontrol activity and induction of systemic resistance in pepper by compost water extracts against Phytophthora capsici. Phytopathology, 100(8): 774-783. https://doi.org/10.1094/PHYTO-100-8-0774

Scheuerell, S. and Mahaffee, W. 2002. Compost tea: principles and prospects for plant disease control. Compost Science \& Utilization, 10(4): 313-338. https://doi.org/10.1080/1065657X.2002.10702095

Scheuerell, S.J. and Mahaffee, W.F. 2004. Compost tea as a con- tainer medium drench for suppressing seedling damping-off caused by Pythium ultimum. Phytopathology, 94: 11561163. Siddiqui, Y., Sariah, M., Razi, I. and Mawardi, R.
2009. Bio-po- tential of compost tea from agro-waste to suppress Cho- anephora cucurbitarum L. the causal pathogen of wet rot of okra. Biological Control, 49: 38-44.

Scheuerell, S.J. and Mahaffee, W.F. 2006. Variability associated with suppression of gray mold (Botrytis cinerea) on geranium by foliar application of non-aerated and aerated compost teas. Plant Disease, 90:1201-1208. https://doi.org/10.1094/PD90-1201

Siddiqui Y, S. Meon, M. R. Ismail and A. Ali, 2008. Trichodermafortified compost extracts for the control of choanephora wet rot in okra production. Crop Prot 27:385-390. https://doi.org/10.1016/j.cropro.2007.07.002

Siddiqui, Y, Meon, S., Ismail M. R. and Ali, A. 2008. Trichodermafortified compost extracts for the control of choanephora wet rot in okra production. Crop Protection, 27: 385-390. https://doi.org/10.1094/PHYTO.2004.94.11.1156

Thomma, P. H. J. Bart. 2003.Pathogen profile Alternaria spp. from general saprophyte to specific parasite. Molecular plant pathology. 4 (4), 225-236. https://doi.org/10.1046/j.13643703.2003.00173.x

Waals, J.E., Korsten, L. and Slippers, B. 2004. Genetic diversity among Alternaria solani isolates from potatoes in South Africa. Plant Disease, 88: 959-964.

https://doi.org/10.1094/PDIS.2004.88.9.959

Walker, J.C. 1971. Fusarium wilt of tomato. American Phytopathological Society, 6: 41-56.

Zhang, W., Han, D.Y., Dick, W.A., Davis, K.R. and Hoitink, H.A.J. 1998. Compost and compost water extract-induced systemic acquired resistance in cucumber and Arabidopsis. Phytopathology, 88: 450-455. https://doi.org/10.1094/PHYTO.1998.88.5.450 